\title{
Atmospheric and Economic Impact of LNG fueled Dredging. The Argentine Case
}

Impacto Atmosférico y Económico del uso de Dragas a GNL. El Caso de Argentina

DOI: https://doi.org/10.25043/19098642.221

Raúl E. Podetti ${ }^{1}$

\begin{abstract}
This paper takes a 2021 Argentine case to show the atmospheric and economic impacts of using LNG fueled dredgers in the second largest worldwide operation of its kind about to start in Rio de la Plata. From the emissions point of view, LNG (Liquified Natural Gas) would reduce 23\%, mainly those (NOx, SOx and PM) affecting the coastal population health. The use of BioLNG would reduce $99 \%(60,000$ Tons/yr), including as well the planetary impact of $\mathrm{CO}_{2}$. The economic impact is estimated in savings of 14\% of Dredging Cost: 665 Million Dollars (MMUsd), over the 15 years of operation. The origin of these savings is $48 \%$ Operational (reduced fuel cost) and 52\% external cost mainly due to the reduced impact in Public Health Budget.
\end{abstract}

Key words: Dredging, Marine LNG, Atmospheric Impact, Economic impact.

\section{Resumen}

Este trabajo toma el caso de Argentina en 2021 para mostrar los impactos atmosféricos y económicos de usar GNL (Gas Natural Licuado) en la propulsión de dragas en la segunda mayor operación mundial de dragado a realizarse en el Rio de la Plata. Del punto de vista de las emisiones, el GNL las reduciría un $23 \%$, actuando principalmente sobre las que afectan a la salud de las poblaciones costeras. El uso de BioGNL las reduce un 99\% (60,000 Tons/a), incluyendo el efecto planetario del $\mathrm{CO}_{2}$. El impacto económico se estima en un ahorro del 14\% del costo total del dragado (665 Millones de dólares) a lo largo de los 15 años de concesión. El 48\% de este ahorro se debe a una reducción de costo de combustible y el $52 \%$ son ahorros de costos externos por el menor gasto necesario en la Salud Pública.

Palabras claves: Dragado, GNL Naval, Impacto Atmosférico, Impacto Económico.

Date Received: April 20th, 2021 - Fecha de recepción: 20 de abril del 2021

Date Accepted: July 3rd, 2021 - Fecha de aceptación: 3 de julio del 2021 ${ }^{1}$ Ingeniero Naval, Investigador Senior. Vector Naval de la Facultad de Ingeniería de la Universidad de Buenos Aires. Argentina. Email:
podettiraul@gmail.com 


\section{Introduction}

In November 2020, the Argentine government launched the bidding process for the new Dredging and Buoying Concession for the inland waterway on the Paraná and Rio de la Plata rivers up to where the latter empties into the Atlantic Ocean. This will make it possible to increase, and afterwards maintain, the width, depth and buoying of the waterways needed to allow some 6,000 ships to circulate with imports and exports from Argentina, Bolivia, Brazil, Paraguay and Uruguay. This is the second largest dredging operation of its kind at global level.

There is a worldwide trend to diminish the harmful effect of dredgers' atmospheric pollution, adopting LNG as fuel, for which reason this study analyzes the atmospheric and economic benefits of this energy transition solution.

\section{Cost of the Investment in Dredgers}

Given that the specific approaches covered in this study relate to the construction of new, environmentally-friendly Trailing Suction Hopper Dredgers (TSHD), here we analyze some cases that assist in estimating the cost of these new constructions.

A ship-owner's first reaction, when thinking about reducing pollution and economizing on the operation by using LNG-fueled dredgers, is to convert his existing dredgers. However, this isn't convenient in the cases of aging vessels since such a conversion demands a very large investment - of the order of $30 \%$ of the value of a new dredger and poses serious space limitations.

A case in point is the transformation to $L N G$ carried out by Damen in 2018 on the Samuel de Champlain dredger, built in 2002, owned by the French company Dragages-Ports Eig for operation at the Port of Nantes-Saint Nazaire (GIE DRAGAGESPORTS, 2017). The investment was of US $\$$ $25 \mathrm{MM}$, equivalent to $29 \%$ of the construction of a new conventional unit, and was subsidized by the
European Commission's Innovation Fund through its Connecting Europe Facility.

In order to estimate the costs of new Trailing Suction Hopper Dredgers, a chart is shown (Fig. 1) (Wowtschuk, B. M. 2016) which indicates the evolution of prices since 1978 as a function of hopper volume. The following cases are indicated on the chart:

1. The building of the dredger Afonso de Albuquerque, owned by Jan de Nul, concluded in 2019 at the Keppel Singmarine shipyards in Nantong, China, at a cost of US $\$ 40 M M$. This value is $6 \%$ higher than that of a conventional dredger owing to the installation of a scrubber system to partially reduce exhaust gas emissions. This equipment has arrived for operation in Argentina (indicated in the color green in the chart).

2. Blue indicates the US\$ $43 \mathrm{MM}$ cost bid by IHC to the Uruguayan National Ports Administration for the dredger 21 de Julio, with a $4,200 \mathrm{~m}^{3}$ hopper, built in Europe. That international tender was canceled and bids sought for the construction of the dredger in Uruguay - which was very successfully carried out in 2017. The new IHC value with partly Uruguayan construction is indicated with a dotted blue line at US\$ 55MM.

3. Lastly, the red line indicates the "design dredger" of this study with a hopper volume of $4,171 \mathrm{~m}^{3}$ which shows a value of US\$ 45MM (US\$ $10,800 / \mathrm{m}^{3}$ of hopper).

In order to consider the extra cost of an LNGpowered dredger over a conventional one, the comparison is made with the case of the pushers (Podetti R.E., 2021) on the Paraguay-Paraná Waterway, for which an estimated extra cost of the order of $25 \%$ was arrived at. As the percentage cost of the motorization of a pusher is relatively higher than that of a dredger, the extra expense of LNG for the latter is considered to be $15 \%$. In this way the designer LNG dredger in this paper is valued at US\$ $51.7 \mathrm{MM}$ (US\$ $12,400 / \mathrm{m}^{3}$ of hopper). 
Fig. 1. TSHD Cost Estimate.

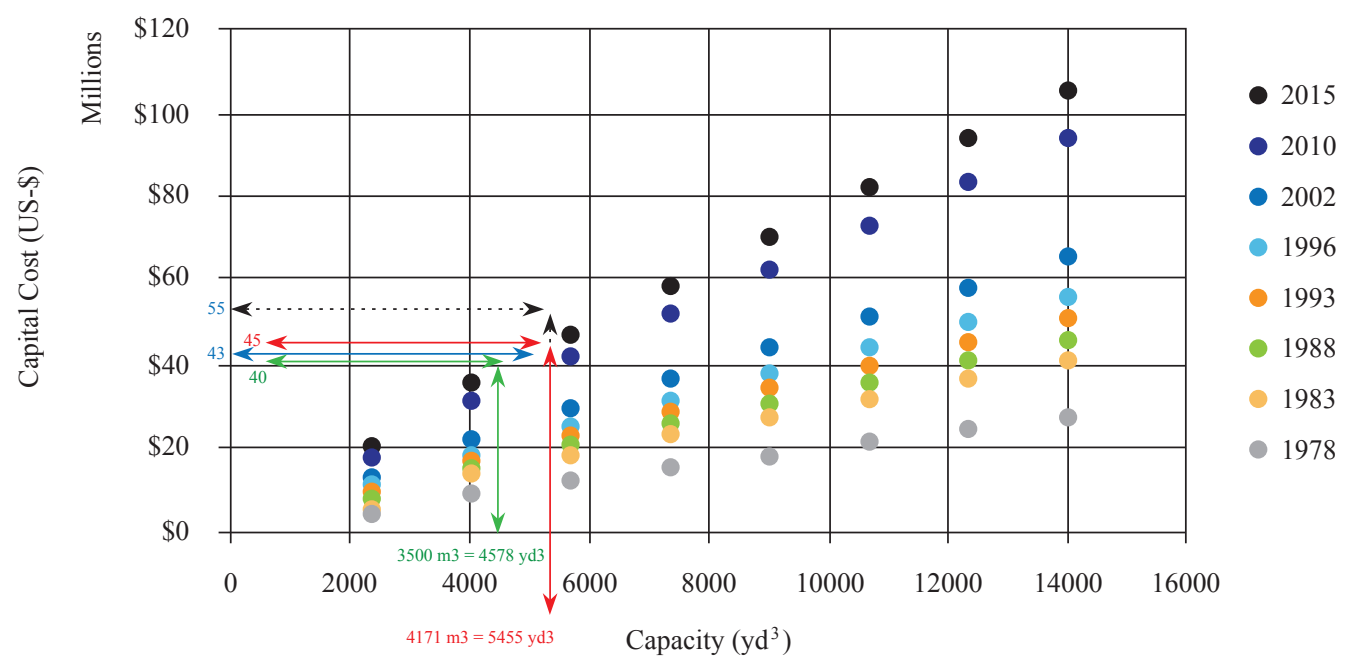

Source: Bohdon Michael Wowtschuk, "Production and cost estimating for trailing suction hopper dredge," Texas A\&M University, Ocean Engineering Dept., 2016. Chart modified by the author.

\section{Dredging Concession in Argentina}

The governmental information (ARGENTINA. HIDROVÍA FEDERAL) on the dredging operation under the current concession is analyzed in order to relate volumes dredged, hours worked, fuel consumption and type of equipment. To do this, the statistics available on the national government's official page were pored (Fig. 2) through, which initially led to the volumes dredged between 1995 and 2017, leading to an annual average of 28.6 million $\mathrm{m} 3$, representing $50 \%$ of

Fig. 2. Argentine Dredging Operation Data 2016-2017.

\begin{tabular}{|c|c|c|c|c|c|c|c|c|c|c|c|}
\hline \multicolumn{2}{|l|}{ DREDGER } & \multirow[t]{2}{*}{$\begin{array}{l}\text { DREDGER } \\
\text { VOLUME }\end{array}$} & \multirow[t]{2}{*}{$\begin{array}{l}\text { TOTAL } \\
\text { POWER }\end{array}$} & \multicolumn{3}{|c|}{2016 (HIGH) } & \multicolumn{3}{|c|}{2017 (LOW) } & \multirow{3}{*}{$\begin{array}{c}2016+2017 \\
\text { DO CONS. } \\
\text { LiTERS }\end{array}$} & \\
\hline & & & & \multicolumn{2}{|c|}{ HOURS /YR } & \multirow{2}{*}{$\begin{array}{c}\text { DO CONS. } \\
\text { LiTERS/YR }\end{array}$} & \multicolumn{2}{|c|}{ HOURS /YR } & \multirow{2}{*}{\begin{tabular}{|c|} 
DO CONS. \\
LiTERS/YR
\end{tabular}} & & \\
\hline Name & No. & M3 & $\mathrm{HP}$ & Operat. & Std By & & Operat. & Std By & & & \\
\hline & & & & $63 \%$ & $18 \%$ & $<\%$ AT $100 \% \mathrm{HP}$ & $63 \%$ & $18 \%$ & $<\%$ AT $100 \% \mathrm{HP}$ & & \\
\hline Niña & 1 & 3.400 & 7.415 & 5.928 & 564 & 5.132 .318 & 4.832 & 618 & 4.222 .100 & 9.354 .418 & \\
\hline Alvar N. C. De Vaca & 2 & 3.400 & 5.494 & 4.913 & 515 & 3.160 .201 & 2.412 & 424 & 1.582 .463 & 4.742 .664 & \\
\hline Americo Vespucci & 3 & 3.500 & 6.968 & 5.451 & 527 & 4.436 .771 & 2.763 & 343 & 2.266 .329 & 6.703 .100 & \\
\hline James Ensor & 4 & 3.600 & 9.849 & 4.557 & 739 & 5.339 .538 & 66 & 29 & 83.272 & 5.422 .810 & \\
\hline Manzanillo & 5 & 4.000 & 16.268 & - & - & - & 3.164 & 423 & 6.075 .101 & 6.075 .101 & \\
\hline Sanderus & 6 & 5.300 & 9.085 & 1.652 & 147 & 1.749 .376 & & & & 1.749 .376 & \\
\hline Capitán Nuñez & 7 & 6.000 & 13.708 & 6.980 & 468 & 11.083.404 & 3.067 & 833 & 5.153 .410 & 16.236 .814 & \\
\hline Pedro A. Cabral & 8 & 14.000 & 21.386 & 1.616 & 314 & 4.148.206 & & & & 4.148 .206 & \\
\hline Niccolo Machiavelli & 9 & & 31.517 & 1.465 & 1.041 & 6.327 .403 & & & & 6.327 .403 & \\
\hline TOTAL HS /YR & & & & 32.562 & 4.315 & & 16.304 & 2.670 & & & \\
\hline TOTAL LIT. D.O. /YR & & & & & & 41.377.219 & & & 19.382.674 & 60.759 .893 & ]$_{1}$ \\
\hline TOTAL VOL DREDGED & & & & & & 53.122 .000 & & & 29.445 .000 & 82.567 .000 & $7_{2}$ \\
\hline $\mathrm{DO} / \mathrm{M3}$ & & & & & & 0,78 & & & 0,66 & 0,74 & $3=1 / 2$ \\
\hline \multirow{2}{*}{\multicolumn{2}{|c|}{ AVERAGE DREDGER VOL. }} & 4.171 & & & & DREDC & ING AVA & LABLE & VOLUME(M3) : & 67.100 & 4 \\
\hline & & & \multicolumn{7}{|c|}{ ANNUAL DREDGING VOLUME (M3) / DREDGING AVILABLE VOLUME: } & 1231 & $5=2 / 4$ \\
\hline
\end{tabular}

Prepared by the author based on (WOWTSCHUK, B. M. 2016) and (ARGENTINA. HIDROVÍA FEDERAL) 
the volume projected (LATINOCONSULT, 2020) for the following period. The dredgers employed were almost exclusively of the TSHD type.

Next, an analysis is performed of the years 2016 and 2017 (with available complete information), which additionally represent two different situations: that for 2016 was of very high dredging activity, while that for 2017 was almost equal to the average for the previous 23 years.

Seven dredgers in operation were taken into consideration along with two additional ones that arrived for operating in one season in 2016. They are all trailing dredgers save one, the Niccolò Machiavelli (9), which is a "cutter."

D.O. Consumption was in each case calculated (Wowtschuk, B. M. 2016) multiplying by parameter 0.1818 , the following factors:

- The dredger's total Power (HP)

- The dredgers' annual Hours of Operation.

- The percentage of Equivalent Hours/day, at $100 \%$ of Power, during Operation.

- The dredgers' annual Stand By Hours.

- The percentage of equivalent Hours/day, at $100 \%$ of Power, during Stand By.

The daily logs for each dredger (ARGENTINA. HIDROVÍA FEDERAL) yielded the Hours of Operation and Hours of Stand By, for each year analyzed.

In order to estimate the Equivalent Hours at 100\% of power for each condition (Operation and Stand By), the values presented in Fig. 3 were employed.

Analyzing this information, the conclusion is that in this two-year period:

- Some 60.8 million liters of D.O. were consumed, and some 82.6 million $\mathrm{m} 3$ were dredged, leading to a specific consumption ratio of $\mathbf{0 . 7 4}$ Liters $\mathrm{D} .0 . / \mathrm{m}^{3}$ dredged.

- In order to achieve the $82.6 \mathrm{MM} \mathrm{m}^{3}$ dredged, dredgers with a total hopper capacity of 67,100 m3 were on hand, making it possible to propose a ratio of $1,231 \mathrm{~m}^{3} \mathrm{dredged} / \mathrm{m}^{3}$ available hopper.

These parameters are highly useful in carrying out the projections for costs, consumption and necessary investments for the new stage.

Fig. 3. Equivalent Hours at 100\% Power.

\section{EQUIVALENT HOURS AT 100\% POWER}

\begin{tabular}{|c|cc|c|c|}
\cline { 2 - 5 } \multicolumn{1}{c|}{} & \multicolumn{3}{|c|}{ OPERATION } & \multicolumn{2}{c|}{ STAND BY } \\
\hline HP & HS/DAY & HS EQ 100\% & HS/DAY & HS EQ 100\% \\
\hline $100 \%$ & 1 & 1,0 & 0 & 0,0 \\
$75 \%$ & 18 & 13,5 & 3 & 2,3 \\
$10 \%$ & 5 & 0,5 & 21 & 2,1 \\
\hline \multicolumn{3}{|c|}{$63 \%$} & 24 & 4,4 \\
\hline
\end{tabular}

Projection for Volume and Total Cost of Dredging and Buoying

The basis adopted was a recent study (LATINOCONSULT, 2020), financed by a series of organizations that represent the interests of sectors which the new concession impacts on.

The information is presented in Fig. 4 and separately analyzed for two geographical sectors: SFC (Santa Fe-Confluencia), to the north, and SFO (Santa FeOcean) to the south; and for two main activities: Dredging and Buoying. At the end the information is unified to obtain median parameters that are easier to handle.

Adding the two sectors together (SFC + SFO), the following overall results are obtained: the total volume of 896 million $\mathrm{m}^{3}$ to be dredged costs 4,153 million dollars (US\$ $4.63 / \mathrm{m}^{3}$ ). Adding the cost of buoy laying for both stretches, some 460 million dollars, a final overall cost of US\$ 4,612 million is reached, which corresponds to a final unit value of US $\$ 5.15 / \mathrm{m}^{3}$ of dredged material (buoying included).

The following table compares the volumes to be dredged in the projected fifteen years with 23 of the 25 years of the current concession for which reliable data were obtained. 
Fig. 4. Dredging Cost.

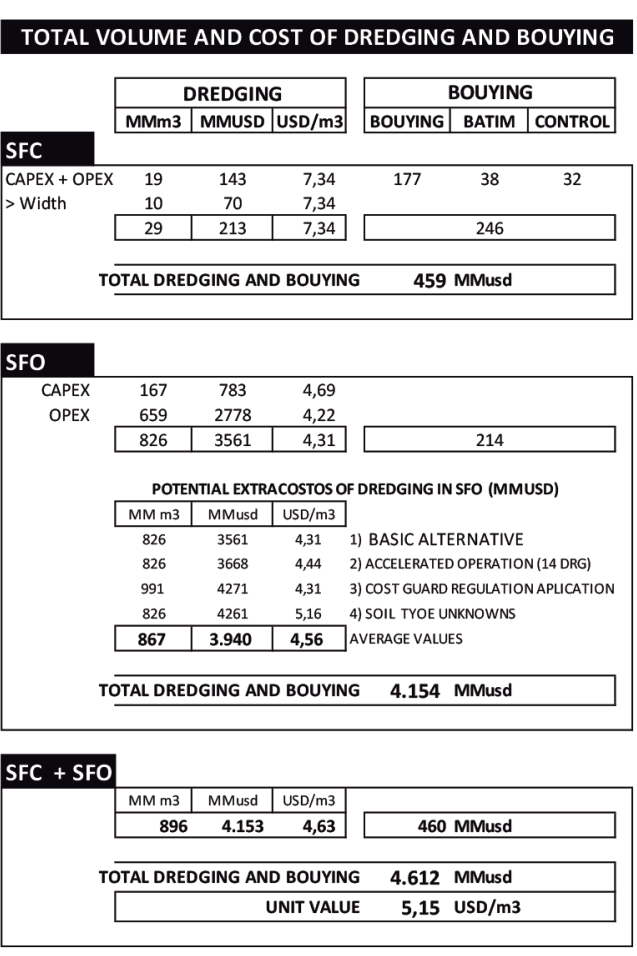

It is seen that the projected dredging effort is somewhat larger than twice what was carried out up to now in annual averages.

As a reference for the evolution of dredging costs over recent years, the following chart presents the U.S. case (in 2018 dollars). The rise is accounted for by increases in fuel, higher environmental demands and the concentration of supply among a few dredging companies, thus reducing real competition.

The following chart (Fig.5) shows the unit cost of dredging (Fritelli, J. 2019) at various U.S. ports and that which is projected for the River Plate. A good correlation with the dredged volume is observed.

\section{Unit Cost of Dredging with LNG}

Fig. 6 details the impact of the use of LNG on the combined result of the Cost of Dredging and Buoying, highlighting the values that are modified with regard to the use of Diesel Oil.

The unit cost is broken down into five factors: Ships, Fuel, Crew + Maintenance, General Expenditures and Others. The table analyzes them separately using the data obtained previously and with parameters from the references (Wowtschuk, B. M. 2016; LATINOCONSULT, 2020 and CIRIA, 2016).

A $7.5 \%$ reduction in the unit cost is seen, which translates into total savings of 321 million dollars. These would be the operational savings with LNG, which lead to greater competitiveness for Argentina's exports.

\section{Toxic Emissions in Dredging Operations}

There is overwhelming scientific evidence with regard to the impact that the toxic emissions of ships, including dredgers, have on health and the

Fig. 5. Dredging Unit Cost.

\begin{tabular}{|l|c|c|}
\cline { 2 - 3 } \multicolumn{1}{c|}{} & MMm3 & USD/m3 \\
\hline Los Angeles & 0,99 & 17,37 \\
New York & 1,44 & 30,53 \\
Detroit & 2,28 & 12,37 \\
San Francisco & 4,10 & 31,97 \\
Alaska & 4,18 & 11,32 \\
Philadelphia & 4,56 & 26,18 \\
Jacksonville & 17,02 & 18,47 \\
Portland & 23,56 & 6,97 \\
Savanah & 28,20 & 8,42 \\
Galveston & 58,52 & 5,00 \\
New Orleans & 80,56 & 3,45 \\
\hline Río de la Plata & $\mathbf{5 9 , 7 4}$ & $\mathbf{4 , 6 3}$ \\
\hline
\end{tabular}

$\mathrm{USD} / \mathrm{m} 3$

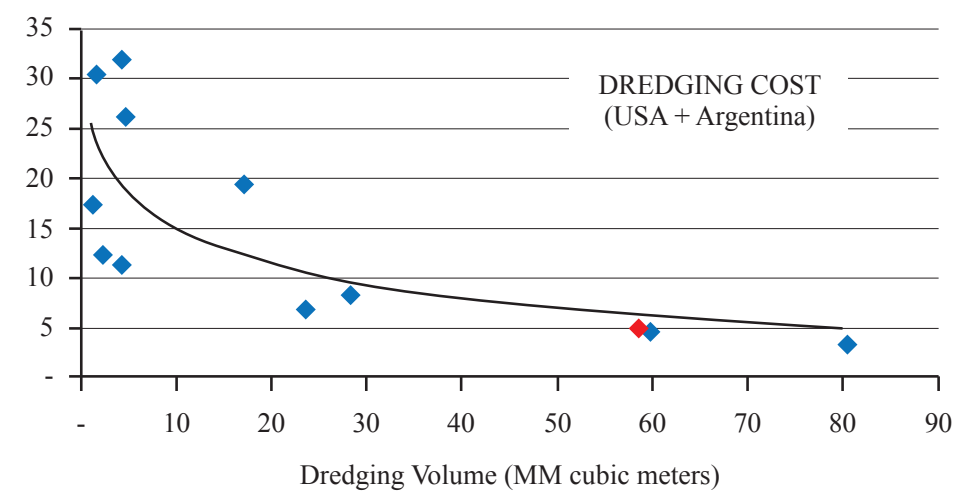


Fig. 6. Dredging Unit Cost Breakdown (LNG).

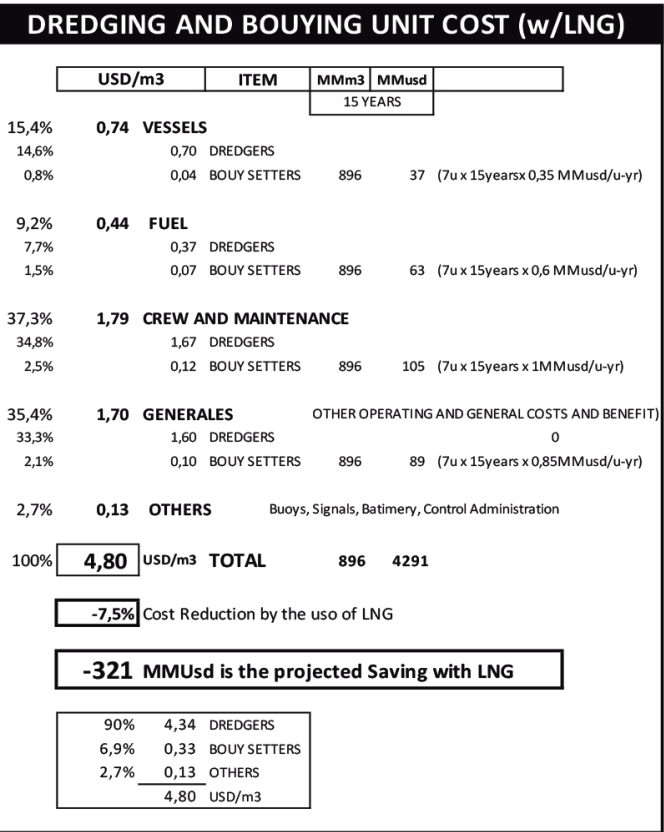

environment, particularly when traffic is intense and contiguous to areas near rivers where there is high population density.

It's interesting to note the corporate position which some global dredging firms are adopting with regard to the issue of pollution, even beyond the minimum regulatory obligations which some consider to be excessively permissive, given the extremely serious worldwide environmental situation. In order to reflect this, the following paragraph is quoted:

"With more than 1,100 dredging vessels worldwide, of which about half are trailing suction hopper dredgers, DEME believes that dredging companies can contribute to the call of the International Maritime Organization (IMO) for improvements in energy efficiency.

The industry should not wait for policies and regulations to rethink the fuel efficiency performance of their dredging vessels, but should achieve sustainable growth by improving energy efficiency with regard to carbon emissions.

Energy objectives at DEME are quantified through an increase in efficiency of $7 \%$ by 2022 compared to 2011." (J.B de Cuyper, 2014)

At present, the replacement of Diesel Oil by Liquid Natural Gas (LNG) on trailing dredgers appears as the most convenient transitional option, for the following reasons:

- The current (and projected) cost of LNG is much lower than that of refined Diesel Oil and this difference is on the rise. The Netherlands Expert Group for Sustainable Transport and Logistics poses price differentials which on average are of $50 \%$ in favor of LNG.

- LNG very strongly reduces emissions that are harmful to health (NOx, SOx and PM).

- It permits being mixed with biogas to thus also reduce $\mathrm{CO}_{2}$ emissions, up to total decarbonization.

- The technology is already tested and widely available on the maritime market with successful applications to new dredgers as well as to others converted from D.O. to LNG.

Nevertheless, to overcome dredgers' specific operational challenges, special designs became necessary that would make it possible to overcome the limitations of the dual (LNG/D.O.) engines applied to dredging (W. Shi et al., 2015). The success of these designs is reflected in the rising percentage of new constructions of LNG-powered dredges.

In the majority of cases, it is necessary to build a new dredger since the large cost of conversion to LNG (of the order of $30 \%$ of a new one) isn't justified in the case of vessels nearing the end of their useful life - which will cause a large part of the fleet to be out of commission earlier than had initially been contemplated.

\section{Unit Cost of Dredging with LNG}

The harm to the environment and to health, caused by the toxic emissions of ships in general, is 
proportional to three factors: Nearness to population, Type of fuel used and Volume consumed.

- The Nearness of the contaminating ship to cities is critical, above all for the health of the most vulnerable populations (children and the aged).

- The Type of fuel consumed causes the specific levels of emissions to vary. Fuel Oil is much more contaminating than Diesel Oil, which in turn is much more contaminating than LNG, which in turn emits more $\mathrm{CO}_{2}$ than biogas.

- The Volume of the harmful emissions generated by ships is proportional to the volume of fuel consumed.

In the case of dredgers and buoy layers, which we are concerned with here, we are in one of the worst situations, since the three factors pointed out combine negatively:

- They operate near the country's largest coastal population centers (metropolitan Buenos Aires-Santa Fe).

- Because of the age of the vessels used under the current concession, in certain cases, the type of fuel is highly contaminating, to which is added a low energy efficiency, this being another factor in the rise in emissions.

- By the high operating intensity of the dredgers and buoy layers, their fuel consumption levels, and therefore those of toxic emissions, are very high.

\section{Volume of Consumption of Diesel Oil}

In order to estimate the volume of fuel during the new concession, current consumption was taken and adjusted in proportion to the volume of dredging.

In Fig, 7 we see that this operation implies a consumption of the order of $52,300 \mathrm{~m}^{3}$ of D.O. yearly by the 17 -vessels fleet of the new concession. As a reference, it is pointed out that this is $77 \%$ of the volume currently consumed by river transport on the Paraguay-Paraná Waterway (Podetti R.e., 2021).

\section{Volume of Emissions}

Fig. 8 presents the Emissions Factor associated with Diesel Oil and LNG for each of the four toxic

Fig. 7. Projected Annual Fuel Consumption of Dredging and Bouying.

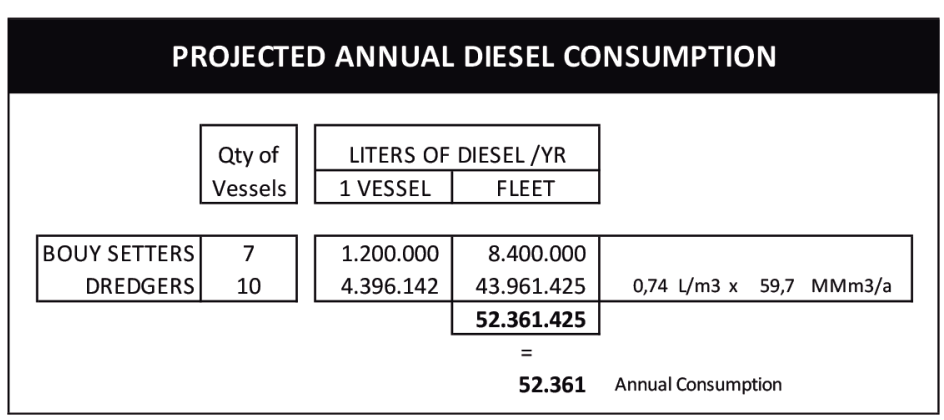

Fig. 8. Projected Annual Emissions of Dredging and Bouying.

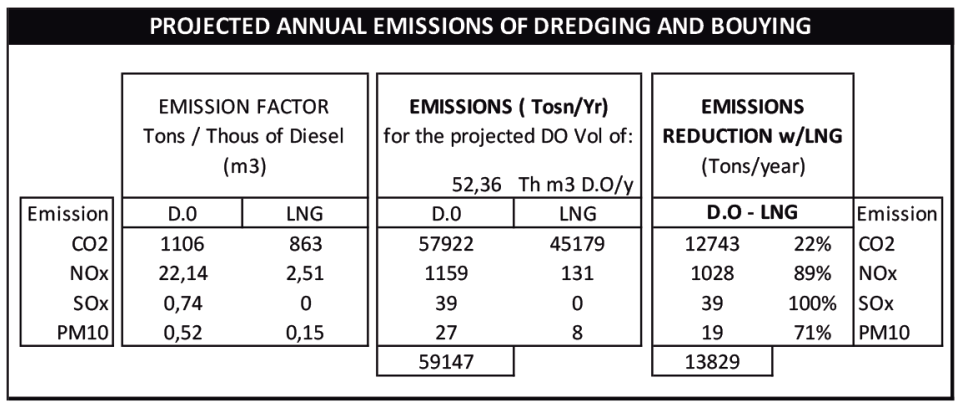


emissions considered. Applying these factors to the annual $52,361 \mathrm{~m}^{3}$ of consumption leads to the annual figure for toxic tons for each case.

Lastly, through the difference, the last column shows the improvement in tons and percentages, clearly demonstrating that the largest percentage improvements are obtained with regard to the emissions that are harmful to health (NOx, SOx and $\mathrm{PM}$ ), and are much more moderate in relation to $\mathrm{CO}_{2}$, which impacts on global warming. To eliminate these $\mathrm{CO}_{2}$ emissions, LNG can be gradually replaced, over the coming years, by BioLNG, as the production of the latter increases in volume and it thus also becomes available for maritime use.

These reduction percentages are somewhat conservative when compared to other, similar studies on the industry (Gabriel, J., 2016) which indicate the following reductions: $25 \%$ for $\mathrm{CO}_{2}$, $85 \%$ for NOx, $99 \%$ for SOx and $99 \%$ for PM.

Economic Assessment of the Damage caused by Toxic Emissions

In a just society, to every crime there corresponds a proportional penalty, which usually has an economic valuation commensurate with the cost of the damage generated. Something similar should occur with contamination, understood as environmental social harm. In Europe, where consciousness over this subject is high and rising, systems of economic penalization of pollution are already in existence. In Argentina (and in many other countries), environmental damages remain unpunished, and very often the problem generated - and therefore its economic impact - are denied.

The toxic emissions of dredgers and buoy tenders generate environmental damages with social costs that are not contemplated by the government and much less so by the concession holder, so that they are termed "external costs." This name seeks to differentiate them from the "internal" costs (fuel, personnel, repairs, etc.) which a ship-owner knows and seeks to minimize since he must pay a price for them.
The environmental costs of ships' emissions remain hidden, yet are very real. They are generated costlessly by the ship-owner, but are paid by the contaminated population, without charging them to the party causing them. This represents an unfair subsidy that fosters the continuation of costless contamination. In Europe, on the other hand, a fairer policy is already beginning to the applied, summarized in the phrase, he who does it, pays for it. This process seeks to "internalize" external costs; in other words, have the shipowners shoulder the costs of the damage through higher taxes on contaminating fuels or, even better, by investing on more environmentally-friendly ships, etc.

\section{External Costs of Dredging in Argentina}

Below we analyze "Argentine external costs" - those that are caused by these vessels' toxic emissions and that increase expenditure on public health because of illnesses and deaths. To which are added the economic losses through damage to infrastructure, harvests and biodiversity, as in the case of the acid rain generated by these harmful emissions.

Since no regional study on the valuation of these damages has been found, the results of European studies (CE DELFT, 2011) are extrapolated. This analysis was performed for the Waterway (Podetti R.e., 2021) and is applied to the case of dredging and buoying, being presented in the following table (Fig.9).

The first line shows the tons of toxic emissions and then the unit external cost for each toxic ton (extrapolating from the European case). It can be seen that particulate matter generates a relatively higher external cost per ton, mainly by being responsible for cardiorespiratory diseases, cancer and deaths among the coastal population.

The conclusion is that, if the current permission to pollute through the use of Diesel Oil in dredging and buoy laying is maintained, we Argentine would pay some US\$ 391MM for the damages which the dredging concessionaire causes all of us as a society, at a pace of US\$ $26 \mathrm{MM} / \mathrm{yr}$. If, instead, 
Fig. 9. Projected Annual External Costs of Dredging and Bouying.

\begin{tabular}{|c|c|c|c|c|c|}
\hline \multicolumn{6}{|c|}{ PROJECTED ANNUAL EXTERNAL COSTS } \\
\hline & PM & NOx & sox & TOTAL & \multirow{5}{*}{$\begin{array}{l}\text { MMUsd/yr } \\
\text { MMUsd }\end{array}$} \\
\hline EMISSIONS VOLUME W/DIESEL (TOns/Yr) & 27 & 1.160 & 39 & & \\
\hline UNIT EXTERNAL COST (Usd/Ton) & 71.560 & 20.265 & 16.133 & & \\
\hline \multirow[t]{2}{*}{ TOTAL EXTERNAL COST (MM Usd/yr) } & 1,93 & 23,51 & 0,63 & 26 & \\
\hline & & & 15 years & 391 & \\
\hline EMISSIONS VOLUME W/LNG (TOns/Yr) & 8 & 131 & - & & \\
\hline UNIT EXTERNAL COST (Usd/Ton) & 71.560 & 20.265 & 16.133 & & \\
\hline \multirow[t]{3}{*}{ TOTAL EXTERNAL COST (MM Usd/yr) } & 0,57 & 2,65 & - & 3 & MMUsd/yr \\
\hline & \multirow{2}{*}{\multicolumn{3}{|c|}{ ANNUAL SAVING: }} & 23 & MMUsd/yr \\
\hline & & & 15 years & 343 & MMUsd \\
\hline
\end{tabular}

the use of LNG were implemented, this cost would be appreciably diminished to only US\$ $3 \mathrm{MM} / \mathrm{yr}$, i.e. to only $11 \%$.

These results coincide by $95 \%$ with those obtained when employing the method proposed (MERK, $O$. 2014) in the OECD's International Transport Forum for ship emissions in port. To this end, the results are related as a function of per capita GDP and the size of the affected coastal populations.

In a way, allowing the use of Diesel Oil is a kind of US\$ 391MM subsidy that the Argentine government awards the concession holder, which neither seems very convenient for the country nor is necessary for the company, which faces a large US $\$ 4.6$ billion business. In addition, in this way the greatest incentive to cease polluting is lost.

\section{External Costs of Dredging on the Planet}

Another aspect which seems remote, but is equally important, is that of the assessment of the "planetary external cost," that is to say the cost related to the climate change that affects all of humanity (current and, above all, future) because of the global warming generated by greenhouse gases, the principal representative of which is $\mathrm{CO}_{2}$.

Fig. 10 (CE DELFT, 2011) shows the projection for the external cost caused by $\mathrm{CO}_{2}$ (euros/ton- $\mathrm{CO}_{2}$ ). Located in the center, between the curves for the two most probable scenarios and for the concession period (2022-2037), is the median value of 80 euros/t- $-\mathrm{CO}_{2}$ (US\$96/t-CO $\mathrm{CO}_{2}$ ). The product of this parameter by the previously calculated volume of $\mathrm{CO}_{2}$ emitted by D.O.-powered dredgers and buoy tenders $\left(57,922 \mathrm{t}-\mathrm{CO}_{2} / \mathrm{yr}\right)$ leads to an annual cost of US\$ 5.6MM, which over the 15 years means US\$ 84MM.

Another way to evaluate the economic cost of this planetary harm caused by $\mathrm{CO}_{2}$ emissions is derived from the very recent "carbon market," which is an indicator of the price paid by those companies that emit $\mathrm{CO}_{2}$ to those with activities that have a negative $\mathrm{CO}_{2}$ balance.

This is a new type of market, which "compensates" those projects that make the biggest efforts in favor of the planet, through the sale and purchase of carbon bonds.

According to the study published by The Economist, the carbon market price (2007) applied to river navigation (PIANC, 2010) is the equivalent of an additional cost of US\$ $0.15 / \mathrm{L}$ of Diesel Oil as a penalty for the emission of $\mathrm{CO}_{2}$.

Applying this to the projected consumption by dredgers and buoy layers under the new concession (52.3 million L D.O./yr), detailed above, leads to a cost of US\$ 8MM/yr., or US\$ 120MM in total, which the company operating the concession ought to pay on the carbon market to compensate for the generated pollution. 
Fig. 10. Projected Planetary External Costs.

$€ /$ TonCO2

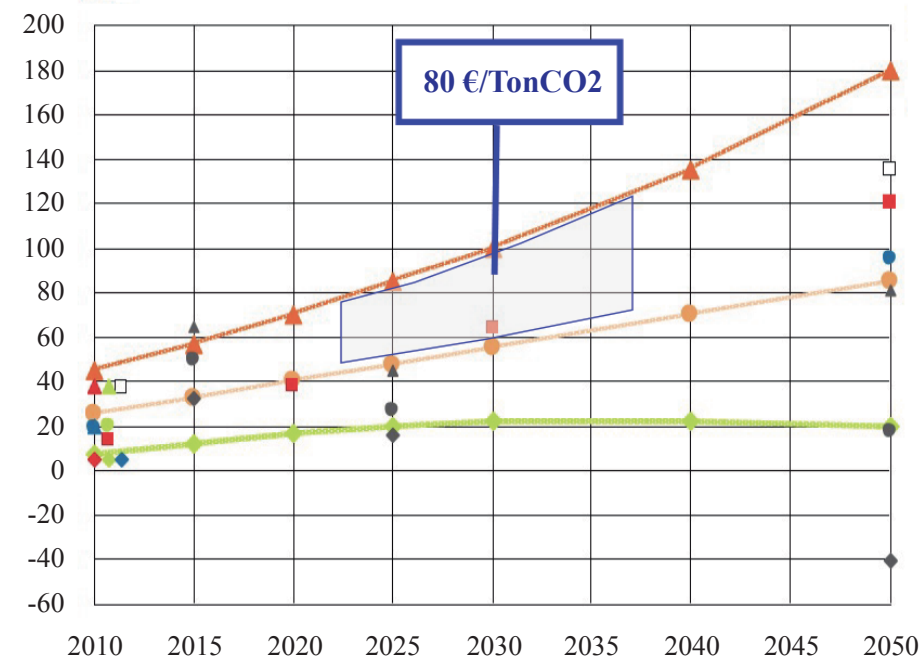

Taking the average between the two monetary assessments, it can be estimated that, using D.O., the future dredging concessionaire on the River Plate will generate a planetary damage with effects on climate change with a value of the order of US\$ 102MM, which could be initially reduced by $22 \%$ with the use of LNG, and by almost $100 \%$ with an increasing use of biogas in propelling the dredgers and buoy layers.

\section{Total External Costs}

The following table (Fig.11) summarizes the external costs detailed above:
In sum, the total external cost which the concession holder would generate if it were allowed to continue using Diesel would be of US\$ 493MM, 79\% of which (US\$ 391MM) would be a hidden subsidy - which Argentines all pay together - issued to the dredging company, for it to continue polluting us for free.

If, instead, the concessionaire were to use LNG, this external cost (mainly social expenditure on health) to Argentina (hidden subsidy) would be reduced by $88 \%$.

Lastly, the use of LNG under the concession allows savings in social expenditures of US\$ 344MM

Fig. 11. Summary of External Costs of Dredging and Bouying.

\begin{tabular}{|c|c|c|c|c|}
\hline \multicolumn{5}{|c|}{ SUMMARY OF EXTERNAL COST OF DREDGING } \\
\hline & \multicolumn{2}{|c|}{ DIESEL } & \multicolumn{2}{|c|}{ REDUCTION W/ } \\
\hline & MMusd & MMUsd/y & LNG & BIOGAS \\
\hline EXTERNAL LOCAL COST & 391 & 26 & $88 \%$ & $99 \%$ \\
\hline (PM10, Sox, Nox) >> HEALTH & $79 \%$ & & & \\
\hline EXTERNAL PLANETARY COST & 102 & 7 & $22 \%$ & $100 \%$ \\
\hline$(\mathrm{CO} 2)>>$ CLIMATE CHANGE & $21 \%$ & & & \\
\hline TOTAL EXTERNAL COST & 493 & 33 & $74 \%$ & 99\% \\
\hline
\end{tabular}


(88\% of 391), and avoids many deaths, protecting our health and that of the planet.

\section{Conclusions}

The use of LNG (and even better bioLNG) to fuel the dredging operations in Argentina would impact in the health of local population and global climate change in a very positive way. But it would also save public funds and operational costs to the operators. Taking the above presented results, there would be large savings in operation and external costs. They are estimated in US\$ 665MM, close to $14 \%$ of total Dredging Cost along the 15 years of concession.

For these reasons, the author has proposed the argentine government to include a simple but powerful clause in the international tender under preparation. This clause sets a limit to the maximum admissible volume of emissions, and on top of that, proposes a method to prize the bidders that guarantee lower emission levels. A heavy monetary penalty is proposed in case of contamination.

A similar clause is proposed to promote the construction of new dredgers in argentine shipyards.

\section{References}

1. CE DELFT, 2011. External Costs of Transport in Europe". Delft, CE, The Netherlands.

2. CIRIA, 2016. A guide to costs and aids for dredging equipment 2009. Construction Industry Research and Information Association, London, UK, 2009, updated to 2016.

3. J.B de CUYPER, 2014. Smart, Sustainable: a Life Cycle Approach to Fuel Economy as Applied to Dredging Vessels, Terra et Aqua, Number 137, December 2014.

4. FRITELLI, J. (2019), Harbor Dedging: Issues and Historical Funding. Congressional
Research Service, Washington DC, USA, November 2019.

5. GABRIEL, J., 2016 - Jan Gabriël, Erik van der Blom. Development of dual fuel $L N G$ hopper dredgers, IHC + DEME Presentation, April 2016.

6. ARGENTINA. HIDROVÍA FEDERAL. Documentos y Estadísticas de la Vía Troncal VTN, DNCPYVN-SSPYVN, avaliable at https://www.argentina.gob.ar/hidroviafederal-2021/informacion-tecnica.

7. LATINOCONSULT, 2020. Servicio de consultoría para el estudio de factibilidad técnicoeconómica del próximo periodo de concesión del sistema de navegación troncal - Informe final, Buenos Aires, Argentina, junio 2020.

8. MERK, O. 2014. Shipping Emission in Ports at International Transport Forum, Paris, France, OECD, 2014.

9. PIANC, 2010. Climate Change and Navigation. Waterborne transport, ports and waterways: A review of climate change drivers, impacts, responses and mitigation, EnviCom Task Group 3, PIANC 2010.

10. PODETTI, R. E. (2021), Hidrovía ParaguayParaná. Inclusiva, Sustentable y Competitiva, Buenos Aires, Vector Naval de la Facultad de Ingeniería de la Universidad de Buenos Aires, Colección Industria Azul. ISBN 978-987-880666-2 - www.industrianaval.com.ar

11. GIE DRAGAGES-PORTS, 2017. Samuel de Champlain to be First LNG-Converted Dredger. Press Release, 2017.

12. W. SHI et al., 2015. Application of $L N G D F$ engines in dredging vessels, in CEDA Dredging Days Conference, Holland, 2015.

13. WOWTSCHUK, B. M. 2016. Production and cost estimating for trailing suction hopper dredge, Texas A\&M University, Ocean Engineering Dept, 2016 